\title{
STRUKTUR KOMUNITAS PLANKTON PERMUKAAN PADA DANAU LABUAN CERMIN KEC. BIDUK-BIDUK, KAB. BERAU
}

\author{
Elis Seftia Arum, Nova Hariani*, Medi Hendra \\ Program Studi Biologi FMIPA Universitas Mulawarman \\ *E-mail: nova.ovariani@gmail.com
}

\begin{abstract}
This study aims to determine (physico-chemical) parameters of water and also community structure of plankton surface in natural tourism Labuan Cermin Biduk-Biduk, Berau, Kalimantan Timur. This study used Purposive Sampling method. Data obtained shows in plankton abundance, diversity index, evenness index and dominance index. The result of study showed that range of temperature between $24,04{ }^{\circ} \mathrm{C}$ $26,88^{\circ} \mathrm{C}$, range of salinity between $0.25-0.87^{\circ} \%$ which classified in freshwater-brackish water, range of power flow between 1.121-2.930 $\mathrm{m} / \mathrm{s}$ which classified in moderate level, the average $\mathrm{pH}$ between 6,767,48 which classified in neutral level, range of TDS between 514-788 $\mathrm{mg} / \mathrm{L}$ which classified in normal level, respectively. Plankton sample showed 27 classes including of 22 classes of phytoplankton with 57 genera and 5 classes of zooplankton with 10 genera. The highest total plankton abundances of 35917 ind/L is in Station $A$ and the lowest total plankton abundances of $8330 \mathrm{ind} / \mathrm{L}$ is in Station F.

Keywords: Plankton, Labuan Cermin, Diversity.
\end{abstract}

Estuari merupakan zona transisi (Ekoton) tempat bersatunya perairan air tawar dan perairan air laut atau asin (Muara sungai, teluk di daerah pesisir, rawa pasang-surut dan badan air yang terpisah dari laut oleh pantai penghalang (barrier beach), merupakan contoh dari sistem perairan estuari (Odum, 1971).

dan $\begin{array}{cll}\text { Pengukuran } & \text { parameter fisika } \\ \text { kimia } & \text { hanya } & \text { dapat }\end{array}$ menggambarkan kualitas lingkungan pada waktu tertentu. Untuk indikator biologi dapat memantau secara kontinyu dan merupakan petunjuk yang mudah untuk memantau terjadinya perubahan pada perairan tersebut. Keberadaan organisme perairan dapat digunakan sebagai indikator terhadap perubahan perairan selain indikator kimia dan fisika. Menurut (Nybakken, 1988;Nontji, 2008) Organisme perairan seperti plankton, nekton dan bentos dapat digunakan sebagai indikator perubahan pada suatu badan perairan karena habitat, mobilitas dan umurnya yang relatif lama mendiami suatu wilayah perairan tertentu.

Plankton merupakan organisme yang hidup melayang didalam air. Organisme ini mempunyai kemampuan gerak yang sangat terbatas, sehingga sebaran organisme ini dipengaruhi oleh kondisi arus perairan. Plankton dapat dibagi menjadi dua yaitu fitoplankton dan zooplankton. Plankton mempunyai peran yang sangat besar dalam ekosistem perairan, karena 
sebagai produsen perairan. Distribusi fitoplankton dipengaruhi oleh ketersediaan cahaya dalam perairan. Kemampuan membentuk zat organik dari zat anorganik dalam perairan menjadikan fitoplankton dikenal sebagai produsen primer (Nontji,1993).

Danau Labuan Cermin yang terletak di Desa Biduk-biduk di Kecamatan Biduk-biduk, Kabupaten Berau, Kalimantan Timur. Danau Labuan Cermin memiliki keistimewaan dimana memiliki perbedaan salinitas antara bagian permukaan, tengah dan dasarnya. Labuan cermin memiliki perbedaan salinitas pada permukaan 0,25$0,87 \%$ o, tengah $15 \%$ o, dasar $>25 \%$ o. Danau Labuan Cermin sendiri merupakan suatu kawasan perairan yang menjorok jauh ke daratan atau yang sering disebut dengan teluk. Perairan ini terletak di sudut paling ujung yang menyerupai danau akibat adanya vegetasi yang mengelilingi dan menutupi bagian litoralnya. Hal tersebut pula yang menyebabkan biota di dalam danau ini sangat beragam. Warna air di Danau Labuan Cermin ini bergradasi dari biru tua, biru muda dan hijau di area luar danau.

Belum ada laporan tentang bagaimana kualitas perairan dikawasan danau Labuan Cermin dengan adanya kegiatan pariwisata dan cahaya matahari yang menembus hingga dasar perairan. Oleh karena itu perlu dilakukan studi untuk mengetahui struktur komunitas plankton dan agar dapat diketahui kualitas perairan berdasarkan struktur komunitas dan keanekaragaman plankton di Danau Labuan Cermin, Kecamatan Biduk-Biduk, Kabupaten
Berau. Penelitian ini bertujuan untuk mengetahui struktur komunitas dan tingkat keanekaragaman plankton permukaan pada Danau Labuan Cermin, Kecamatan Biduk-Biduk, Kabupaten Berau serta kulaitas perairan berdasarkan faktor kimia dan fisika.

\section{METODE}

1. Waktu dan tempat

Penelitian ini dilaksanakan dari bulan Januari sampai dengan bulan Juli 2016, yang terbagi dalam 2 tahap penelitian, yaitu tahap pertama pengambilan sampel di Danau Labuan Cermin Kecamatan Bidukbiduk, Kabupaten Berau, Kalimantan Timur dan tahap kedua identifikasi sampel di Laboratorium Ekologi dan Sistematika Hewan, FMIPA, Universitas Mulawarman, Samarinda.

2. Alat dan bahan

Alat-alat yang diperlukan diantaranya Plankton net, GPS (Global Positioning System), water checker, $\mathrm{pH}$ meter, keping secchi, botol sampel, sprayer, ember, spidol permanen, kamera DSLR, timba/ember, pipet tetes, object glass, cover glass, gelas ukur, tisue, mikroskop, alat tulis, dan buku panduan identifikasi plankton sedangkan bahan yang digunakan antara lain sampel plankton, aquadest, dan formalin $4 \%$.

3. Teknik sampling

Stasiun pengambilan sampel ditentukan menggunakan metode Purposive Sampling. Pada penelitian ini ditetapkan 6 stasiun pengambilan sampel yang masing-masing stasiun terdiri dari 2 titik.

4. Pengambilan sampel

Pengambilan sampel

dilakukan di lima stasiun dengan dua 
titik disetiap stasiun sampling dan satu stasiun sampling dilakukan secara horizontal pada permukaan perairan, plankton net yang ditarik perahu dengan kecepatan konstan. Penentuan pengambilan sampel berdasarkan hasil pengamatan pendahuluan selama 1 hari sebelum penelitian dilakukan, sebelum sampel plankton diambil, ditentukan titik koordinat dengan menggunakan GPS (Global Positioning System) di setiap titik. Untuk mendapatkan hasil yang akurat, dilakukan pengulangan sebanyak dua kali pagi dan siang, dilakukan pengukuran kondisi fisik kimia perairan pada pagi hari sebelum melakukan sampling. Salinitas, suhu, $\mathrm{pH}$ dan TDS diukur dengan menggunakan water checker, kemudian dicatat hasilnya. Sampling plankton dilakukan dengan menggunakan Plankton-Net no.30, kemudian sampel yang masih melekat disaringan disemprot dengan aquadest menggunakan sprayer, kemudian dipindahkan ke botol sampel dan ditambahkan formalin 4\% sebanyak 1-3 tetes, serta diberi label dengan spidol permanen.

Sampel plankton yang telah diperoleh, dibawa ke laboratorium untuk di identifikasi. Kemudian jenis plankton yang diperoleh dicatat dan didokumentasi menggunakan kamera, lalu diidentifikasi dengan menggunakan buku identifikasi Newell \& Newell (1977), Tomas (1996), Hutabarat \& Evans (1985), Rose (1957) dengan cara menyesuaikan bentuk dan ciri-ciri plankton yang di temukan. Selanjutnya dilakukan perhitungan kelimpahan plankton yang diperoleh dan dianalisa indeks keanekaragaman, indeks keseragaman dan indeks dominansi.

5. Teknik analisis data

Struktur komunitas plankton diketahui melalui parameter kelimpahan plankton $(\mathrm{N})$, indeks keanekaragaman jenis $\left(\mathrm{H}^{\prime}\right)$, indeks keseragaman (E) dan indeks dominansi (D).

\section{HASIL DAN PEMBAHASAN}

Hasil pengukuran beberapa parameter kualitas air yang meliputi sifat fisika dan kimia perairan yang dapat dilihat pada Tabel 1. Suhu perairan yang diukur selama penelitian tidak menunjukan perbedaan yang cukup besar antar stasiun pengamatan. Tabel 1. memperlihatkan bahwa suhu pagi dan siang di 6 stasiun pengamatan berkisar antara $24,0{ }^{\circ} \mathrm{C} \quad-26,9{ }^{\circ} \mathrm{C}$. Adanya perbedaan suhu antar stasiun diduga karena adanya dan tidak adanya naungan dari vegetasi disekitar danau.

Menurut Barus (2004), pola suhu ekosistem air dipengaruhi oleh berbagai faktor seperti intensitas cahaya matahari, pertukaran panas antara air dengan udara sekelilingnya, ketinggian geografis dan juga oleh faktor kanopi (penutupan oleh vegetasi) dari pepohonan yang tumbuh ditepi. Salinitas merupakan nilai yang menunjukan jumlah garamgaram terlarut dalam satuan permil $(\%)$. Hasil pengukuran salinitas pada Tabel 1. di atas terlihat bahwa salinitas berkisar antara $0,25-0,87^{\circ}$ oo. Nilai tersebut tergolong dalam perairan tawar-payau. Menurut Lembaga Oseanologi Nasional (2009), bahwa air dengan salinitas 0$0,5 \%$ digolongkan air tawar dan salinitas $0,5-30 \%$ digolongkan air 
payau serta air dengan salinitas $>30 \%$ digolongkan asin.

Hasil pengukuran salinitas pada Tabel 1 di atas terlihat bahwa kekuatan arus berkisar antara 1,121-2,930 m/detik. Menurut Barus (2004), arus air adalah faktor yang mempunyai peranan yang sangat penting baik pada perairan lotik maupun pada perairan lentik. Hal ini berhubungan dengan penyebaran organisme, gas-gas terlarut dan mineral yang terdapat di dalam air. Kecepatan aliran air akan bervariasi secara vertikal. Arus air pada perairan lotik umumnya bersifat turbulen yaitu arus air yang bergerak ke segala arah sehingga air akan terdistribusi ke seluruh bagian dari perairan, pada ekosistem lentik arus dipengaruhi oleh kekuatan angin, semakin kuat tiupan angin akan menyebabkan arus semakin kuat, sangat sulit untuk membuat suatu batasan mengenai kecepatan arus.

Tabel 1. Rata-rata faktor fisika dan kimia air yang diukur selama penelitian di Labuan Cermin

\begin{tabular}{|c|c|c|c|c|c|c|c|c|c|c|c|c|c|}
\hline \multirow{3}{*}{ No } & \multirow{3}{*}{ Parameter } & \multicolumn{12}{|c|}{ Stasiun } \\
\hline & & \multicolumn{2}{|c|}{$\mathbf{A}$} & \multicolumn{2}{|c|}{ B } & \multicolumn{2}{|c|}{$\mathbf{C}$} & \multicolumn{2}{|c|}{ D } & \multicolumn{2}{|c|}{$\mathbf{E}$} & \multicolumn{2}{|c|}{ F (Horizontal) } \\
\hline & & Pagi & Siang & Pagi & Siang & Pagi & Siang & Pagi & Siang & Pagi & Siang & Pagi & Siang \\
\hline $\mathbf{A}$ & Fisika & & & & & & & & & & & & \\
\hline 1. & Suhu $\left({ }^{\circ} \mathrm{C}\right)$ & 24,3 & 25,4 & 24,6 & 26,6 & 25,0 & 26,9 & 24,3 & 25,3 & 24,0 & 25,5 & 24,8 & 26,8 \\
\hline 2. & $\begin{array}{c}\text { Salinitas } \\
(\%)\end{array}$ & 0,66 & 0,75 & 0,25 & 0,61 & 0,38 & 0,72 & 0,57 & 0,77 & 0,45 & 0,73 & 0,55 & 0,87 \\
\hline 3. & $\begin{array}{c}\text { Kekuatan } \\
\text { Arus } \\
\text { (m/detik) }\end{array}$ & 2,077 & 2,938 & 1,325 & 1,353 & 1,262 & 1,285 & 1,242 & 1,258 & 1,121 & 1,137 & 1,827 & 1,564 \\
\hline B & Kimia & & & & & & & & & & & & \\
\hline 1. & $\mathrm{pH}$ & 7,3 & 7,3 & 6,8 & 6,8 & 7,5 & 7,5 & 7,2 & 7,3 & 7,1 & 7,1 & 6,9 & 6,8 \\
\hline 2. & $\begin{array}{c}\text { TDS } \\
(\mathrm{mg} / \mathrm{L})\end{array}$ & 719 & 718 & 629 & 642 & 514 & 517 & 726 & 719 & 559 & 562 & 788 & 773 \\
\hline
\end{tabular}

Derajat keasaman atau $\mathrm{pH}$ merupakan suatu indeks kadar ion hidrogen $(\mathrm{H}+)$ yang mencirikan keseimbangan asam dan basa. Dari hasil pengukuran yang dilakukan diperoleh nilai Derajat Keasaman yang normal pada semua stasiun penelitian dengan nilai rata-rata 6,76 7,48 (Tabel 1.). Menurut

Kristanto (2002), nilai $\mathrm{pH}$ air yang normal adalah sekitar $6-8$, sedangkan $\mathrm{pH}$ air yang tercemar misalnya air limbah (buangan), berbeda-beda tergantung pada jenis limbahnya. Hasil pengukuran TDS selama penelitian pada semua stasiun berkisar antara 514-788 mg/L (Tabel 1.). Konsentrasi TDS di dalam perairan sangat bervariasi karena adanya nilai kelarutan mineral yang berbeda dalam suatu daerah geologi. Konsentrasi TDS dalam air berikatan dengan granit, pasir silika, dan bahan yang tidak terlarut lainnya. Menurut PP no 82 tahun 2001 nilai baku mutu untuk TDS maksimum sebesar 1000 $\mathrm{mg} / \mathrm{L}$.

\section{Kelimpahan Plankton}

Hasil penelitian menunjukan bahwa pengambilan sampel yang dilakukan pada 2 (dua) waktu yang berbeda yaitu pagi dan siang hari pada 6 (enam) stasiun pengamatan diperoleh jenis dan kelimpahan plankton syang dapat dilihat pada Gambar 1. Plankton yang ditemukan terdiri dari 27 kelas. Komposisi kelimpahan plankton menurut kelasnya, terdapat perbedaan yang 
besar.antara kelas. Hasil dapat dilihat pada Gambar 1. dibawah ini. Kelas Bacillariophyceae (diatom) sebanyak 211.380 ind/ L.dan Chlorophyceae sebanyak 55.550 ind/ L merupakan dua kelas yang paling banyak ditemukan. Menurut (Whitton and Sinclair, 1975) bahwa pada perairan berarus lebih dari 0,5-1 $\mathrm{m} / \operatorname{detik}$, spesies yang mendominasi adalah spesies dari kelas Bacillariophyceae atau lebih dikenal dengan nama Diatom. Begitu pula dengan penelitian Dianthani (2003) diperairan Muara Badak Kabupaten Kutai Kartanegara Kalimantan Timur. Kelas Bacillariophyceae juga mendominasi di stasiun penelitiannya. Ariana dkk. (2013), bahwa banyaknya kelas Bacillariophyceae diperairan disebabkan oleh kemampuan beradaptasi dengan lingkungan yang ekstrim. Kelimpahan Bacillariophyceae diduga juga disebabkan salinitas yang relatif tinggi.

Hasil pengamatan yang telah dilakukan perbandingan antara fitoplankton dan zooplankton pada tiap-tiap stasiun pengamatan yang dilakukan baik pada pagi maupun siang hari, menurut Barus (2004), bahwa kepadatan zooplankton disuatu perairan lotik (mengalir) jauh lebih sedikit dibandingkan fitoplankton. Fitoplankton memiliki siklus hidup yang lebih cepat dibandingkan zooplankton. Keberadaan zooplankton yang lebih rendah merupakan kondisi yang alami sebagai kelompok organisme yang berada pada trofik level yang lebih tinggi dari fitoplankton. Hal ini disebabkan pengambilan sampel yang hanya daerah permukaan perairan dan pada saat pengambilan sampel zooplankton berada dibawah permukaan perairan. Hutabarat \& Evans (1984), yang menambahkan bahwa fitoplankton umumnya dapat dijumpai pada lapisan permukaan perairan. Kelas Rotifera ditemukan paling sedikit dibandingkan dengan kelas lain karena hanya ditemukan pada satu stasiun pengamatan. Kelimpahan plankton cukup bervariasi pada tiap-tiap stasiun pengamatan. Pada stasiun A di dapatkan total kelimpahan 137.450 individu/liter, pada stasiun B didapatkan total kelimpahan 78.100 ind/L, pada stasiun $\mathrm{C}$ didapatkan total kelimpahan 126.150 ind/L, pada stasiun D didapatkan total kelimpahan $87.850 \mathrm{ind} / \mathrm{L}$. pada stasiun E didapatkan total kelimpahan 98.650 individu/liter, pada stasiun $\mathrm{F}$ didapatkan total kelimpahan 67.750 ind/L.

Perbedaan jumlah ind/L di 6 stasiun pengamatan dapat dilihat pada Gambar 2. Berdasarkan Gambar 2 terlihat bahwa, kelimpahan plankton yang tertinggi terdapat pada stasiun A yaitu total kelimpahan 137.450 ind/L sedangkan kelimpahan individu terendah terdapat pada stasiun $\mathrm{F}$ yaitu total kelimpahan 67.750 ind/L. Hal ini diduga karena adanya perbedaan kondisi masing-masing stasiun. Menurut Nontji (2008), menjelaskan bahwa konsentrasi plankton bisa ribuan bahkan jutaan sel per liter air sehingga menyebabkan distribusi plankton diperairan tidaklah merata antara habitat yang satu dengan habitat yang lainnya. Kelimpahan plankon pada stasiun A lebih tinggi dari stasiun lainnya hal ini diduga karena stasiun ini di jalur masuk dan keluarnya air laut ke dalam Labuan cermin dengan arus kuat. 


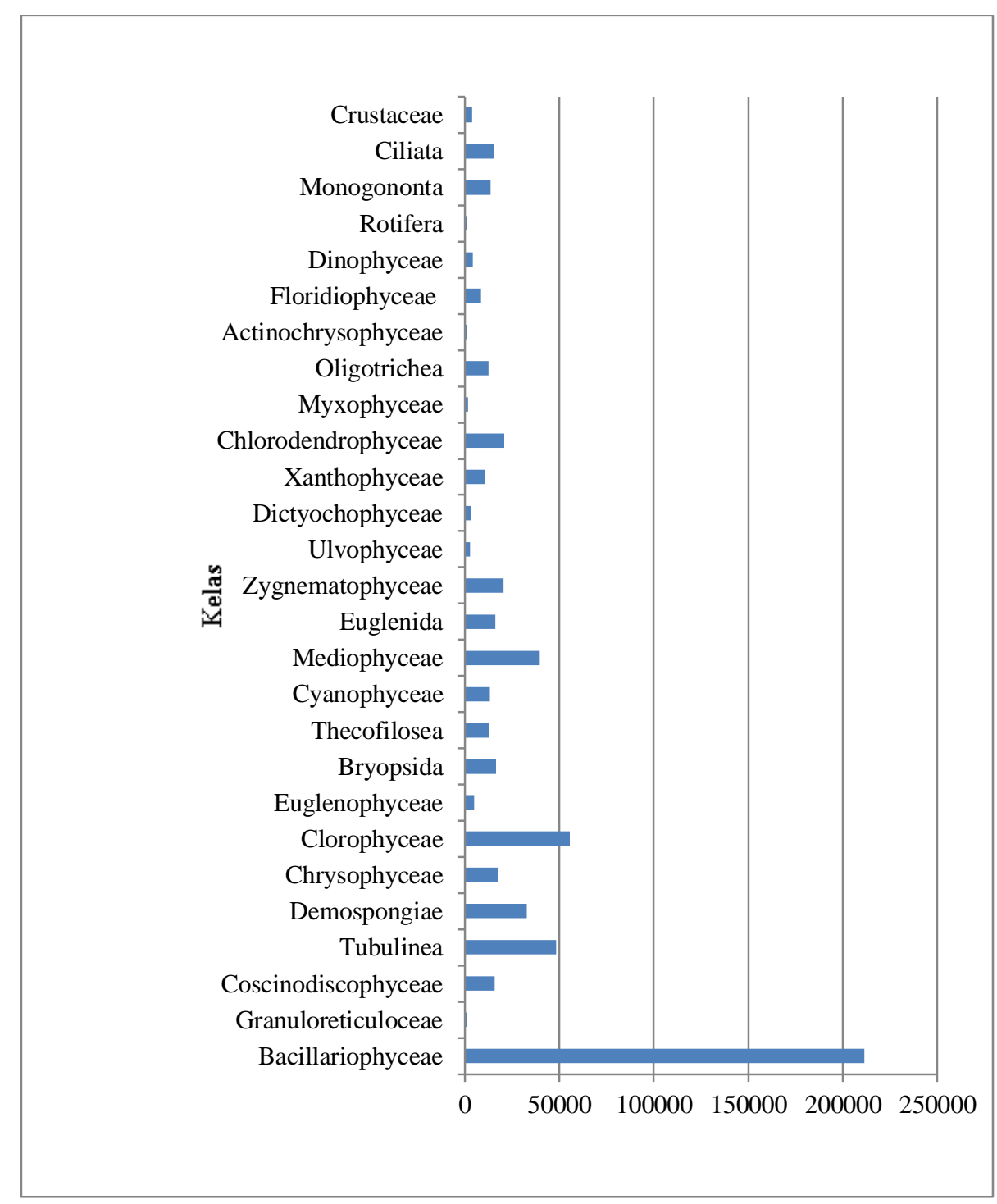

Gambar 1. Total kelimpahan plankton berdasarkan kelasnya di Labuan Cermin

Total kelimpahan plankton pada stasiun $\mathrm{F}$ cendrung lebih rendah dari pada stasiun lainnya. Hal ini diduga karena pada stasiun ini terdapat banyak aktivitas pengujung seperti berenang dan menjadi tempat untuk memutar kapal bermotor yang di sewa pengunjung untuk kembali ke dermaga sehingga proses fotosintesis tidak berjalan secara optimal selain kondisi danau pada stasiun ini juga tidak ada arus air yang juga berpengaruh terhadap jumlah kelimpahan plankton yang ditemukan pada stasiun $\mathrm{F}$ ini. 


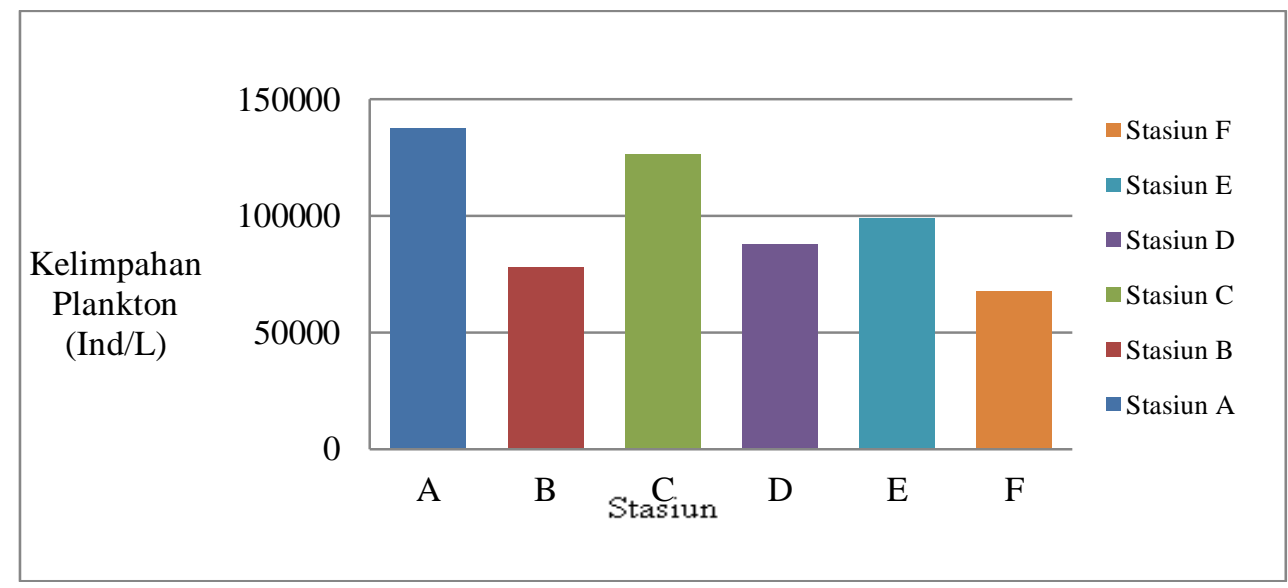

Gambar 2. Total kelimpahan plankton perstasiun pengamatan di Labuan Cermin

2. Nilai Indeks Keanekaragaman (H')

Hasil perhitungan terhadap kelimpahan plankton maka diperoleh nilai indeks keanekaragaman (H') plankton masing-masing spesies setiap stasiun. Dari Tabel 2. Terlihat bahwa kisaran rata-rata keanekaragaman berkisar antara 2,774-3,196 dengan keanekaragaman tertinggi terdapat pada Stasiun C siang hari sebesar 3,196. Tingginya keanekaragaman pada stasiun ini disebabkan oleh kondisi faktor fisika kimia air yang mendukung bagi pertumbuhan plankton seperti $\mathrm{pH}$ yang normal serta faktor fisika kimia lainnya yang mendukung kelangsungan hidup plankton. Selain itu pada stasiun ini tidak ada aktivitas pengunjung seperti berenang dan pada stasiun ini juga cahaya matahari langsung masuk kebadan perairan karena tidak terhalangi oleh vegetasi disekitarnya. Keanekaragaman terendah pada stasiun B pagi hari sebesar 2,774, hal ini disebabkan pada kondisi lingkungan yang terdapat pada stasiun B yakni daerah yang paling banyak terdapat aktivitas masyarakat seperti benerang, main air dan menjadi tempat persinggahan kapal motor pengunjung.

Tabel 2. Rerata indeks keanekaragaman (H') plankton di Labuan Cermin

\begin{tabular}{ccc}
\hline \multirow{2}{*}{ Stasiun } & \multicolumn{2}{c}{ Waktu } \\
\cline { 2 - 3 } & Pagi & Siang \\
\hline A & 3,048 & 3,055 \\
\hline B & 2,774 & 2,828 \\
\hline C & 3,020 & 3,196 \\
\hline D & 2,847 & 2,975 \\
\hline E & 2,999 & 2,990 \\
\hline F & 2,980 & 3,192
\end{tabular}

Menurut Barus (2004), keanekaragaman rendah bila $0<\mathrm{H}^{\prime}<$ 2,302 keanekaragaman sedang bila
$2,302<\mathrm{H}^{\prime}<6,907$ keanekaragaman tinggi bila $\mathrm{H}^{\prime}>6,907$ Berdasarkan kriteria tersebut dapat disimpulkan 
bahwa semua stasiun penelitian mempunyai tingkat keanekaragaman sedang. suatu komunitas dikatakan mempunyai keanekaragaman spesies yang tinggi apabila terdapat banyak spesies dengan jumlah individu masing-masing spesies yang relatif merata, dengan kata lain apabila suatu komunitas hanya terdiri dari sedikit spesies dengan jumlah individu yang tidak merata, maka komunitas tersebut dapat dikatakan rendah. Menurut Begon et al (1996) nilai diversitas berdasarkan indeks Shannon - Wiener dihubungkan dengan tingkat pencemaran yaitu apabila $H^{\prime}<1$ tercemar berat, apabila nilai $1<\mathrm{H}^{\prime}<3$ tercemar sedang dan apabila nilai $\mathrm{H}^{\prime}>3$ tidak tercemar atau bersih. Dari kategori di atas kita dapat menarik kesimpulan bahwa seluruh stasiun penelitian termasuk pencemaran pada tingkat tercemar sedang. Nilai indeks keanekaragaman tidak hanya ditentukan oleh banyaknya jenis yang ditemukan namun ditentukan pula oleh jumlah individu masing-masing jenis, seperti yang dikemukakan oleh (Edi, 2003 dalam Septiyatmaja, 2007).

\section{Nilai Indeks Dominansi (D)}

Hasil perhitungan terhadap kelimpahan plankton maka diperoleh nilai indeks dominansi (D) plankton masing-masing spesies setiap stasiun.

Tabel 3. Rerata Indeks Dominansi (D) Plankton di Labuan cermin.

\begin{tabular}{ccc}
\hline \multirow{2}{*}{ Stasiun } & \multicolumn{2}{c}{ Waktu } \\
\cline { 2 - 3 } & Pagi & Siang \\
\hline A & 0,052 & 0,057 \\
\hline B & 0,072 & 0,069 \\
\hline C & 0,058 & 0,054 \\
\hline D & 0,071 & 0,056 \\
\hline E & 0,053 & 0,053 \\
\hline F & 0,055 & 0,044
\end{tabular}

Tabel 3. menunjukkan bahwa kisaran rata-rata Indeks Dominasi pada masing-masing stasiun penelitian rata-rata berkisar antara 0,044-0,072 dengan nilai indeks dominansi tertinggi terdapat pada stasiun B pagi sebesar 0,072 dan dominansi terendah terdapat pada stasiun F sebesar 0,044. Menurut Krebs (1985) nilai indeks dominansi (D) berkisar antara 0-1, dominansi tergolong rendah bila nilainya mendekati 0 dan tergolong tinggi bila mendekati 1. Nilai indeks dominansi yang diperoleh mendekati 0 yang berarti tidak ada spesies yang mendominasi pada perairan Danau
Labuan cermin Kecamatan Bidukbiduk Kabupaten Berau. Hal ini sesuai dengan pendapat yang dikemukakan oleh Fahrul (2007), bahwa kisaran indeks dominansi ini memiliki jumlah individu tiap jenis hampir sama atau tidak ada yang mendominansi.

\section{SIMPULAN DAN SARAN}

Hasil penelitian dan analisis data yang telah dilakukan maka diperoleh kesimpulan sebagai berikut:

1. Keadaan lingkungan (fisika dan kimia) di Danau Labuan Cermin Kec.Biduk-biduk, Kab.Berau yaitu suhu berkisar antara $24,04^{\circ} \mathrm{C}$ - 
$26,88^{\circ} \mathrm{C}$, salinitas berkisar antara $0,25-0,87 \%$ digolongkan perairan air tawar-payau, kekuatan arus berkisar antara 1,121-2,930 m/detik digolongkan kekuatan arus sedang, nilai $\mathrm{pH}$ rata-rata berkisar antara 6,76-7,48 tergolong netral, nilai TDS berkisar antara 514-788 $\mathrm{mg} / \mathrm{L}$ termasuk dalam kisaran TDS normal.

2. Plankton yang ditemukan pada seluruh stasiun penelitian adalah 27 kelas. Nilai total kelimpahan plankton tertinggi terdapat pada stasiun A sebesar $35.917 \mathrm{ind} / \mathrm{L}$ dan Nilai total kelimpahan plankton terendah terdapat pada stasiun $\mathrm{F}$ sebesar 8.330 ind/L.

3. Nilai indeks keanekaragaman (H') tertinggi terdapat pada stasiun $\mathrm{C}$ sebesar 3,196 dan keanekaragaman (H') terendah pada stasiun B sebesar 2,774. Nilai indeks dominasi tertinggi terdapat pada stasiun B sebesar 0,072 dan dominansi terendah terdapat pada stasiun F sebesar 0,044, Semua stasiun cenderung seragam sehingga tidak ada spesies yang mendominansi.

Perlu adanya monitoring secara berkala terhadap kondisi dan kualitas perairan di Labuan Cermin sehingga dapat diketahui perkembangan kualitas perairan baik dari manfaatnya maupun dari segi ekologi.

\section{DAFTAR PUSTAKA}

Ariana, D., Joko, S., \& Syafrudin, N. (2013). Komposisi Jenis dan Kelimpahan Fitoplankton Perairan Laut Riau. Universitas Riau.

Barus, T. A. (2004). Pengantar Limnologi Studi Tentang
Ekosistem Air Daratan. Medan: USU Press.

Begon, M., Mortimer, M., \& Thompson, D. J. (1996). Population Ecology: A Unified Study of Animals and Plants, Third Edition

Dianthani, D. (2003). Identifikasi Jenis Plankton di Perairan Muara Badak, Kalimantan Timur. Makalah Falsafah Sains Program Pasca Sarjana / S3 Institut Pertanian Bogor. Retrivied Mei 2003

Fachrul, M. F. (2007). Metode Sampling Bioekologi. Jakarta: Bumi Aksara.

Hutabarat, S \& Evans, M. (1985). Pengantar Oseanografi. Jakarta: VC Press.

Krebs, C. J. (1985). Experimental Analysis of Distribution of Abudance. Third Edition. New York: Haper \& Row Publisher.

Kristanto. (2002). Ekologi Industri. Yogyakarta: Penerbit ANDY.

Lembaga Oseanografi nasional (LIPI). (2009). Pemetaan Habitat Laut Dangkal. Jakarta: LIPI

Newell, C. E \& Newel R. C. (1977). Marine Plankton A Proctical Guide. London: Departemen of zoology.

Nontji, A. (1993). Laut Nusantara. ISBN 979428204 11. 362 hal. Jakarta: Penerbit Djambatan.

Nontji, A. (2008). Plankton Laut. ISBN 9789797990855. 
56 Jurnal Pendidikan Matematika dan IPA Vol. 9 No. 1 Januari 2018: 47-56

331 hal. Jakarta: Penerbit LIPI Press.

Nybakken, J. W. (1988). Biologi Laut suatu Pendekatan Ekologis. Jakarta: PT. Gramedia.

Odum, E.P. (1971). Fundamentals of Ecology. Third edition. W.B. Saunders Company, Philadelphia, London: Toronto, $574 \mathrm{pp}$.

Rose, M. (1957). Manuel de Planctonologie Mediterraneenne. Paris: Central National De La Recherche Scientique.

Septiyatmaja, I. (2007), Studi Keanekaragaman Plankton Di Danau Jempang Desa Tanjung Isuy Kecamatan Jempang Kabupaten Kutai Barat. Skripsi Fakultas MIPA UNMUL Samarinda: Tidak Dipublikasi.
Sutjianto, R. (2003). Biodiversitas Plankton Sebagai Indikator Kualitas Perairan. Makassar: Universitas Hasanuddin.

Tomas, R. (1996). Identifying Marine Diatom and Dinoflagellates. California: Academik Press Inc.

Whitton, B. A. \& Sinclair, C. (1975). Ecology of Blue-green Algae. Science Progress (1933-). 62(247) 429-446. 